\title{
Bacteria belonging to the genus Bacillus associated with three species of solitary bees *
}

\author{
M Gilliam ${ }^{1 * *}$, SL Buchmann 1, BJ Lorenz 1, RJ Schmalzel 2*** \\ 'US Department of Agriculture, Agricultural Research Service, Carl Hayden Bee Research Center, \\ 2000 East Allen Road, Tucson, Arizona 85719 USA; \\ 2 Smithsonian Tropical Research Institute, APDO 2072, Balboa, Panamá
}

(Received 26 July 1989; accepted 31 October 1989)

\begin{abstract}
Summary - Brood provisions from Centris flavofasciata and Xylocopa californica arizonensis, larval feces and pollen collected by $X c$ arizonensis, and the alimentary canal of adult female Crawfordapis luctuosa were examined for micro-organisms, particularly spore-forming bacteria belonging to the genus Bacillus. Bacillus species were associated with some samples from all 3 bees. Brood provisions of $C$ flavofasciata contained $B$ licheniformis. Bacillus cereus, $B$ subtilis, and an unidentified Bacillus similar to $B$ sphaericus were isolated from the gut of Crawfordapis. Pollen collected by $X C$ arizonensis contained $B$ circulans, $B$ pumilus, and $B$ subtilis. The latter species was also associated with provisions of a young carpenter bee larva. These results and our previous findings on microflora of Anthophora sp, Apis mellifera, Centris pallida, Melipona fasciata, and a necrophage of the genus Trigona demonstrate that Bacillus species are common associates of Apoidea and could participate both in metabolic conversion of food and in the control of competing and/or spoilage microorganisms.
\end{abstract}

\section{Apoidea / micro-organism / Bacillus}

From our previous results which demonstrated the association of spore-forming bacteria belonging to the genus Bacillus with the stored food of both social and solitary species of Apoidea, we postulated that female bees may inoculate food with Bacillus species which could pre-digest, convert, and/or preserve stored food (Gilliam, 1979; Gilliam et al, 1984, 1985, 1990). Since Bacillus species are recog- nized and utilized for their ability to produce and secrete numerous enzymes, antibiotics, and fatty acids, they could play a role both in the metabolic conversion of food of bees and in the control of competing or spoilage microbes.

Associations of Bacillus species with pollen collected and stored by honey bees, Apis mellifera (Gilliam, 1979), and by a stingless bee, Melipona quadrifasciata

\footnotetext{
* Mention of a proprietary product or company name does not constitute an endorsement by the US Department of Agriculture.

** Correspondence and reprints.

*** Present address: Biology Department, University of lowa, lowa City, lowa 52240 USA.
} 
(Machado, 1971), have been reported. Machado (1971) also found at least 1 species of Bacillus in the larval food of 13 stingless bee species. Gilliam et al (1984, 1985) examined larval provisions of Anthophora sp, Centris pallida, and an obligate necrophage of the genus Trigona and found that all contained $1-5$ species of $\mathrm{Ba}$ cillus but no other micro-organisms. The same species of Bacillus ( $B$ circulans, $B$ iicheniformis, $B$ megaterium, $B$ pumilus, and $B$ subtilis) were found in glandular cell provisions made by the Trigona in the tropical wet forest and in pollen collected and stored as bee bread by $A$ mellifera in the Arizona desert. Bacillus circulans was isolated from larval provisions of the solitary, soil-nesting bees, Anthophora sp and $C$ pallida; $B$ coagulans, $B$ firmus, and $B$ megaterium were also present in provisions of $C$ pallida. Recently, we reported $B$ alvei, $B$ circulans, and $B$ megaterium from stored food of a social stingless bee, Melipona fasciata, from Panamá (Gilliam et al, 1990). Bacillus megaterium was isolated from brood provisions, pollen from storage pots, and honey from storage pots. The 2 other species of Bacillus were found in a few honey and brood provision samples but not in stored pollen. Few other microorganisms were found.

In this paper, we report Bacillus species associated with 3 species of solitary bees. Unfortunately, solitary bees and their provisions are not readily obtainable. Nesting sites are difficult to locate, and bees and provisions are present only for a few days or weeks within the year. Centris flavofasciata samples were collected in Guanacaste Province, Costa Rica in February 1986. Crawfordapis luctuosa adult females were obtained in October 1983 from a nesting aggregation described by Roubik and Michener (1985) in Chiriquí Province, Panamá. Samples from the carpenter bee, Xylocopa californica arizonensis, from Box
Canyon in the Santa Rita Mountains in southern Arizona were collected in May 1986. The first 2 bee species nest in soil; $X$ $c$ arizonensis nests in the previous season's infructescences of Agave, Yucca, and Dasylirion (Agavaceae). Centris and $X y l o c o p a$ are anthophorids, and Crawfordapis is a colletid bee.

Bees and cells were frozen at $-20^{\circ} \mathrm{C}$ and/or freeze-dried until samples (table I) were removed for microbiological analyses for bacteria, molds, and yeasts by procedures previously described (Gilliam et al, 1985, 1990). Adult Crawfordapis female bees were surface-sterilized with ethanol, rinsed in $\mathbf{3}$ washes of sterile distilled water, and dissected under sterile conditions to remove the alimentary tract which was divided into 2 sections, esophagus plus crop and ventriculus through rectum, each of which was individually homogenized in 1 $\mathrm{ml}$ of sterile distilled water and then plated. Pollen and fecal pellets from Xylocopa were also homogenized before plating. The pollen sample had been collected by the female, mixed with nectar, and stored outside the cells against the burrow wall close to the entrance hole. Brood provisions from individual cells were plated directly. Nutrient agar, TYG (tryptic soy agar with glucose and yeast extract), Czapek solution agar, YM-1 agar, and thioglycollate medium incubated at $25^{\circ} \mathrm{C}$ and $37^{\circ} \mathrm{C}$ were the isolation media. Thioglycollate medium was used to test for the presence of microaerophilic and anaerobic organisms, and any growth in these tubes was transferred to nutrient agar and TYG plates. When growth on these media was poor, plates of brain heart infusion agar were also inoculated. Plates were incubated aerobically, under $5 \% \quad \mathrm{CO}_{2}$, and anaerobically to determine whether the organisms were facultative, microaerophilic, or anaerobic. 
Table I. Micro-organisms associated with 3 solitary bees. ${ }^{a}$ EC $=$ esophagus and crop; ${ }^{b}$ VR $=$ ventriculus through rectum; ${ }^{c}$ ND $=$ not determined.

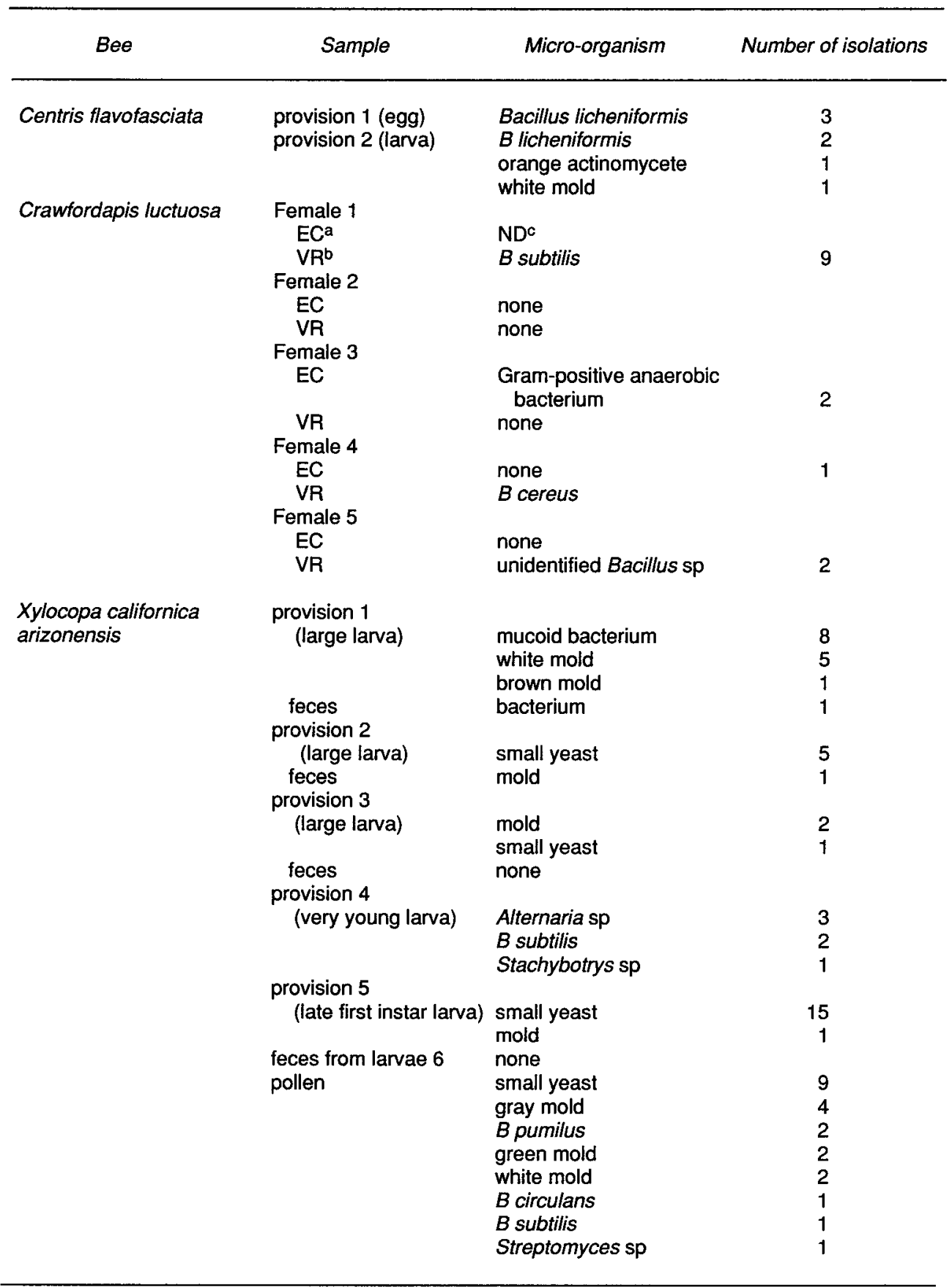


Bacillus species were associated with some of the samples from each of the 3 bee species tested (table I). Brood provisions of $C$ flavofasciata contained $B$ licheniformis. Bacillus cereus, $B$ subtilis, and an unidentified Bacillus, which gave reactions in taxonomic tests that were closest to those for $B$ sphaericus, were isolated from the gut but not the crop of Crawfordapis adult females bees. Pollen collected by $X C$ arizonensis contained $B$ circulans, $B$ pumilus, and $B$ subtilis. The latter species was also isolated from provisions containing a young carpenter bee larva.

Pollen (74\% Prosopis, 22\% Fouquieria, $4 \%$ Argemone, $0.4 \%$ Liliaceae, $0.4 \%$ miscellaneous legumes) collected and stored by $X \subset$ arizonensis contained the same $\mathrm{Ba}$ cillus species as almond, Prunus dulcis, pollen collected and stored by $A$ mellifera with the exception of $B$ megaterium (Gilliam, 1979). Bacillus licheniformis and $B$ subtilis, species isolated from brood provisions in the present experiment, were also found previously in brood provisions of the necrophage of the genus Trigona (Gilliam et al, 1985). Bacillus cereus and $B$ subtilis, isolated from Crawfordapis ventriculus-rectum, have been reported from the alimentary canal of $\boldsymbol{A}$ mellifera workers (Gilliam and Valentine, 1976; Gilliam and Morton, 1978) and queens (Gilliam, 1978).

Since the aim of our study was to determine associations of Bacillus species and bees, detailed efforts were not made to identify other micro-organisms that were isolated. From the limited samples available for analyses, it appears that diverse microbial associations as found previously for $\boldsymbol{A}$ mellifera (Gilliam, 1989) may occur with the carpenter bee, $X \subset$ arizonensis, since bacteria, yeasts, and molds were isolated.

Since 3 of 5 female Crawfordapis contained Bacillus species in the gut, exami- nation of additional bees and brood provisions, which were unavailable when our collections were made, are necessary to determine whether Bacillus species are responsible for the absence of other microbes in the gut and whether they are transferred to provisions. Microbiological data from $C$ pallida (Gilliam et al, 1984) and $C$ flavofasciata show the association of Bacillus, although of different species, with Centris.

As a screening process to assess potential enzymatic contributions by the $\mathrm{Ba}$ cillus species isolated, strains were tested for production of 19 enzymes with the API ZYM system as previously described (Gilliam et al, 1985). Ten of the 19 enzymes were produced by strains associated with each of the 3 bees, although the specific enzymes varied (table II). All strains produced caprylate esterase-lipase. Enzymes produced in the highest concentrations were as follows: acid phosphatase ( $\geq 40$ nanomoles) by $B$ cereus and $B$ subtilis from Crawfordapis, chymotrypsin $(\geq 30$ nanomoles) by $B$ circulans from pollen collected by Xylocopa and by $B$ subtilis from Crawfordapis, alkaline phosphatase $(\geq 30$ nanomoles) by $B$ pumilus from pollen collected by $X y l o c o p a$, caprylate esteraselipase ( $\geq 30$ nanomoles) by $B$ pumilus and $B$ subtilis from pollen collected by $X y / o c o-$ $p a$, and leucine aminopeptidase ( $\geq 30$ nanomoles) by $B$ subtilis from Crawfordapis.

Results from taxonomic tests showed that all isolates produced catalase. All isolates from $C$ flavofasciata and Xylocopa produced proteases that hydrolyzed casein; all from Xylocopa fermented glucose with acid production and produced proteases that liquefied gelatin; all from Centris produced amylase, reduced nitrates to nitrites, and fermented glucose, arabinose, mannitol, and trehalose with acid production; and all from Centris and Crawfordapis and most from Xylocopa grew in acid $\mathrm{pH}$ 
Table Il. Summary of enzymes produced by Bacillus species associated with 3 species of solitary bees. ${ }^{a} \mathrm{~V}=$ variable.

\begin{tabular}{|c|c|c|c|}
\hline Enzyme & $\begin{array}{c}\text { Centris } \\
\text { flavofasciata }\end{array}$ & $\begin{array}{l}\text { Crawfordapis } \\
\text { luctuosa }\end{array}$ & $\begin{array}{l}\text { Xylocopa } \\
\text { californica } \\
\text { arizonensis }\end{array}$ \\
\hline Alkaline phosphatase & + & + & V \\
\hline Butyrate esterase & va & - & v \\
\hline Caprylate esterase-lipase & + & + & + \\
\hline Myristate lipase & - & - & - \\
\hline Leucine aminopeptidase & + & $v$ & + \\
\hline Valine aminopeptidase & - & v & v \\
\hline Cystine aminopeptidase & - & - & - \\
\hline Trypsin & - & V & - \\
\hline Chymotripsin & v & + & V \\
\hline Acid phosphatase & v & + & V \\
\hline Phosphamidase & v & + & V \\
\hline$\alpha$-Galactosidase & - & - & - \\
\hline$\beta$-Galactosidase & + & - & - \\
\hline$\beta$-Glucuronidase & - & - & - \\
\hline$\alpha$-Glucosidase & + & V & V \\
\hline$\beta$-Glucosidase & v & V & V \\
\hline N-Acetyl- $\beta$-glucosaminidase & - & - & - \\
\hline$\alpha$-Mannosidase & - & - & - \\
\hline$\alpha$-Fucosidase & - & - & - \\
\hline
\end{tabular}

and at high osmotic pressure. Otherwise, there was variability in these characteristics with the exception of the failure of isolates from Crawfordapis to ferment arabinose, mannitol, and xylose.

Therefore, based on results from taxonomic tests and the API ZYM system, isolates from provisions of Centris were the most active with regard to carbohydrate catabolism, and those from the ventriculusrectum of Crawfordapis were the least active. Isolates from all sources produced enzymes involved in protein and lipid catabolism. These data provide information on the biochemical capabilities of the bacteria, but further work is necessary to ascertain how they relate to the metabolism and biochemistry of the bees.
Our work on the association of Bacillus species and bees is continuing as more material becomes available. After these surveys are completed, more detailed research will be required to assess the $d y$ namics, ecology, and specific contributions of these micro-organisms to bees.

\section{ACKNOWLEDGMENT}

We thank Dr Lyn Loveless, University of Kansas, for help in freeze-drying the specimens of Crawfordapis luctuosa in Panamá.

Résumé - Bactéries appartenant au genre Bacillus associées à trois es- 
pèces d'abeilles solitaires. Afin de poursuivre l'inventaire des bactéries sporulantes à Gram positif du genre Bacillus, nous avons mené une étude microbiologique des provisions à couvain de Centris flavofasciata et de Xylocopa californica arizonensis, du tube digestif de la femelle adulte de Crawfordapis luctuosa, des fécès de larves de $X c$ arizonensis et du pollen collecté par celle-ci. Des espèces de Bacillus ont été trouvées dans certains échantillons de ces 3 abeilles. Les provisions à couvain de $C$ flavofasciata contenaient $B$ licheniformis. $B$ cereus, $B$ subtilis et un Bacillus non identifié, semblable à $B$ sphaericus, ont été isolés de l'intestin de Crawfordapis. Le pollen récolté par $X c$ arizonensis contenait $B$ circulans, $B$ pumilus et $B$ subtilis. Cette dernière espèce était aussi associée aux provisions d'une jeune larve de xylocope.

Ces résultats sont comparés avec les précédents concernant la microflore d'Anthophora sp, Apis mellifica, Centris pallida, Melipona fasciata et une abeille nécrophage du genre Trigona. Ils montrent que les espèces de Bacillus sont communément associées aux Apoïdes. Ces bactéries pourraient prendre part, à la fois à la transformation métabolique de la nourriture des abeilles et à la lutte contre les micro-organismes concurrents qui gâtent la nourriture.

\section{Apoidea / microorganisme / Bacillus}

Zusammenfassung - Bakterien aus
der Gattung Bacillus, die bei drei Arten
Solitärer Bienen vorkommen. Um zusätzliche Bienenarten auf das Vorkommen Gram-positiver, sporenbildender Bakterien aus der Gattung Bacillus zu überprüfen, wurden mikrobiologische Untersuchungen durchgeführt an 1) BrutNahrungsvorräten von Centris flavofasciata; 2) dem Verdauungstrakt adulter Weib- chen von Crawfordapis luctuosa; 3) BrutNahrungsvorräten, Larven-Fäzes und Pollen aus Nestern von Xylocopa californica arizonensis. Bei allen diesen drei Bienen wurden in einigen Proben Bacillus-Arten gefunden. Die Brutnahrung von $C$ flavofasciata enthielt $B$ licheniformis. Bacillus cereus, $B$ subtilis und ein unbestimmter Bacillus, ähnlich dem $B$ sphaericus, wurden aus dem Darm von Crawfordapis isoliert. Der von $X c$ arizonica gesammelte Pollen enthielt $B$ circulans, $B$ pumilus und $B$ subtilis. Letzere Art kam auch in den Vorräten einer jungen Larve der Holzbiene vor. Diese Resultate werden mit unseren früheren Ergebnissen über die Mikroflora von Anthophora, Apis mellifera, Centris pallida, Melipona fasciata und einem Nekrophagen (Aasfresser) der Gattung Trigona verglichen. Sie zeigen, daß Bacillus-Arten bei den Apoidea ganz allgemein vorkommen. Diese Bakterien könnten sowohl an der metabolischen Umwandlung der Bienennahrung wie an der Kontrolle der konkurrierenden, die Nahrung verderbenden Mikroorganismen beteiligt sein.

\section{Apoidea / Mikroorganismus / Bacillus}

\section{REFERENCES}

Gilliam M (1978) Bacteria belonging to the genus Bacillus isolated from selected organs of queen honey bees, Apis mellifera. $J$ invertebr Pathol 31, 389-391

Gilliam M (1979) Microbiology of pollen and bee bread: the genus Bacillus. Apidologie 10, 269-274

Gilliam M (1989) Microbial ecology of honey bees. The XXXIst Int Cong of Apiculture, Warsaw, Poland, 1987, Apimondia Publ, Bucharest, 217-220

Gilliam M, Valentine DK (1976) Bacteria isolated from the intestinal contents of foraging worker honey bees, Apis mellifera: the genus $\mathrm{Ba}$ cillus. J Invertebr Pathol 28, 275-276 
Gilliam M, Morton HL (1978) Bacteria belonging to the genus Bacillus isolated from honey bees, Apis mellifera, fed 2,4-D and antibiotics. Apidologie 9, 213-222

Gilliam M, Buchmann SL, Lorenz BJ (1984) Microbial flora of the larval provisions of the solitary bees, Centris pallida and Anthophora sp. Apidologie 15, 1-10

Gilliam M, Buchmann SL, Lorenz BJ, Roubik DW (1985) Microbiology of larval provisions of the stingless bee, Trigona hypogea, an obligate necrophage. Biotropica 17, 28-31
Gilliam M, Roubik DW, Lorenz BJ (1990) Microorganisms associated with pollen, honey, and brood provisions in the nest of a stingless bee, Melipona fasciata. Apidologie 21, 89-97

Machado JO (1971) Simbiose entre as abelhas sociais brasileiras (Meliponinae, Apidae) e uma especie de bacteria. Cienc Cult (Sao Paulo) 23, 625-633

Roubik DW, Michener CD (1985) Nesting biology of Crawfordapis in Panama (Hymenoptera, Colletidae). J Kans Entomol Soc 57, 622671 